\title{
How does pedogenesis drive plant diversity?
}

\author{
Etienne Laliberté ${ }^{1}$, James B. Grace ${ }^{2}$, Michael A. Huston ${ }^{3}$, Hans Lambers ${ }^{1}$, \\ François P. Teste ${ }^{1}$, Benjamin L. Turner ${ }^{4}$, and David A. Wardle ${ }^{5}$
}

\author{
${ }^{1}$ School of Plant Biology, The University of Western Australia, 35 Stirling Highway, Crawley, WA 6009, Australia \\ ${ }^{2}$ US Geological Survey, National Wetlands Research Center, 700 Cajundome Boulevard, Lafayette, LO 70506, USA \\ ${ }^{3}$ Department of Biology, Texas State University, San Marcos, TX 78666, USA \\ ${ }^{4}$ Smithsonian Tropical Research Institute, Apartado 0843-03092, Balboa, Ancon, Republic of Panama \\ ${ }^{5}$ Department of Forest Ecology and Management, Faculty of Forestry, Swedish University of Agricultural Sciences, SE901-83 \\ Umeå, Sweden
}

\begin{abstract}
Some of the most species-rich plant communities occur on ancient, strongly weathered soils, whereas those on recently developed soils tend to be less diverse. Mechanisms underlying this well-known pattern, however, remain unresolved. Here, we present a conceptual model describing alternative mechanisms by which pedogenesis (the process of soil formation) might drive plant diversity. We suggest that long-term soil chronosequences offer great, yet largely untapped, potential as 'natural experiments' to determine edaphic controls over plant diversity. Finally, we discuss how our conceptual model can be evaluated quantitatively using structural equation modeling to advance multivariate theories about the determinants of local plant diversity. This should help us to understand broader-scale diversity patterns, such as the latitudinal gradient of plant diversity.
\end{abstract}

\section{Links between plant diversity and pedogenesis}

One of the most striking global ecological patterns is the increase in plant diversity from the poles to the equator [1]. This increase in diversity at lower latitudes coincides with a global gradient in soil development, whereby lowerlatitude soils tend to be older and more strongly weathered (see Glossary) compared with higher-latitude soils [2,3] (Box 1). This raises the question: is plant diversity linked to pedogenesis and, if so, what mechanisms are involved?

Identifying causal links between pedogenesis and plant diversity across broad latitudinal gradients is problematic, because many factors co-vary with latitude. However, the global pattern of increasing plant diversity with pedogenesis is reproduced at local scales along well-defined soil-age gradients from around the world [4,5] (Box 1). We propose that these 'soil chronosequences' (Box 2) offer considerable potential for evaluating multiple hypotheses for this increase in plant diversity with soil age.

This article has three sections. First, we present a set of hypotheses about how pedogenesis might drive local plant species diversity (Figure 1). Second, we discuss how these

Corresponding author: Laliberté, E. (etienne.laliberte@uwa.edu.au).

$0169-5347 / \$$ - see front matter

(C) 2013 Elsevier Ltd. All rights reserved. http://dx.doi.org/10.1016/j.tree.2013.02.008

\section{Glossary}

Base saturation: proportion of negatively charged soil exchange sites occupied by base cations [i.e., calcium $\left(\mathrm{Ca}^{2+}\right)$, magnesium $\left(\mathrm{Mg}^{2+}\right), \mathrm{K}^{+}$, and sodium $\left.\left(\mathrm{Na}^{+}\right)\right]$.

Horizon: soil layer, parallel to the soil surface, with physical, chemical, or biological characteristics that are distinct from the layers above or below it, and usually differentiated based on color, texture, and organic matter.

Humus: relatively stable soil organic matter that does not retain structural characteristics of the plant or animal tissues from which it originates.

Indicator variable: observed variable that serves as an indirect measure of a quantity of causal interest in a structural equation model [6].

Kaolinite: aluminosilicate clay mineral with low cation exchange capacity, common in old, strongly weathered soils.

Mycorrhizal network: network of mycorrhizal fungi that connect plants together via hyphal links [39].

Natural experiment: field study where variation in a driving factor (e.g., soil nutrient availability or time since disturbance) is controlled via careful site selection, rather than by imposed experimental treatments.

Nutrient stoichiometry: the relative abundance of plant elements in the environment or in biomass. In particular, the N:P ratio is often emphasized, because they are the two nutrients that most often limit terrestrial plant productivity. More broadly, ecological stoichiometry is the balance of multiple chemical substances that affect, and are affected by, organisms, and that influence ecological interactions and processes [56].

Oxisol: an order in Soil Taxonomy, the US soil classification system. Oxisols are defined as soils with an oxic horizon [i.e., containing $<10 \%$ weatherable minerals in the fine sand fraction $(50-200 \mu \mathrm{m})$ and a low cation-exchange capacity] or a kandic horizon (clay enriched and low cation-exchange capacity) with $>40 \%$ clay in the surface soil. Oxisols represent soils that have undergone extreme weathering, are low in nutrients, and occur predominantly in stable regions of the lowland tropics.

Parent material: original material from which a soil is derived.

Pedogenesis: the process of soil formation, generally leading to the formation of soil horizons. The five major soil-forming factors are: parent material, organisms, topography, climate, and time [57].

Plant-soil feedback: process by which an individual plant modifies its local abiotic or biotic soil properties, which in turn influences its own performance and that of other plants.

Resource partitioning: occurs when two (or more) co-occurring individuals use different resources (or different forms of the same resource), thereby reducing competition between them.

Soil chronosequence: a series of soils that are derived from similar parent material but differ in time since initiation of pedogenesis (Box 2). Variation in other soil-forming factors (i.e., climate, topography, parent material, and organisms) is minimized along a soil chronosequence [50,51]. In most soil chronosequences, sites have not experienced constant climate and vegetation throughout their pedogenic development, but current climate, parent material, and topography are usually well constrained.

Structural equation modeling (SEM): framework where a (generally multivariate) hypothetical causal model is first specified and then evaluated quantitatively against data [6].

Weathering: physical, chemical, and biological processes through which less stable (e.g., primary) minerals are converted to more stable minerals. In relatively young soils, weathering is the main source of rock-derived nutrients (e.g., P). 


\section{Box 1. Long-term pedogenesis and local plant species diversity}

Although there is a wide diversity of soils in both tropical and temperate regions, the most strongly weathered soils in the world (Oxisols) occur almost exclusively in the tropics, and underlie vast areas of hyperdiverse lowland tropical forest. Conversely, many soils at higher latitudes have been rejuvenated following recent glaciations. The best known and most extreme cases of high local (i.e., alpha) plant diversity on strongly weathered soils come from tropica rainforests [11] (Figure I). For example, lowland tropical rainforest in Yasuní National Park (Ecuador) can contain up to 644 tree species ha $^{-1}$ [58]. Soils in the Yasuní region are strongly weathered, very acidic, kaolinitic, have high exchangeable aluminum (Al) concentrations and very low base saturation [59]. Another example of hyperdiverse tropical rainforest on strongly weathered soils in the Asian tropics is the Lambir Hills National Park (Sarawak, Malaysia), where up to 610 tree species $\mathrm{ha}^{-1}$ can be found, with the greatest diversity on infertile Ultisols [60].

High alpha diversity on strongly weathered soils is not, however restricted to tropical rainforests (Figure I). Some areas of the Brazilian cerrado moist savannah biome show relatively high plant alpha diversity of up to 120 tree or shrub species ha ${ }^{-1}$ [61]; cerrado soils are deep, infertile Oxisols [62]. In addition, species-rich fynbos vegetation of South Africa (up to 114 species $0.1 \mathrm{ha}^{-1}$ ) [63] also occurs on ancient, nutrient-impoverished soils. Similarly, some southwestern Australia kwongan shrublands show high local species richness (up to 121 species $0.1 \mathrm{ha}^{-1}$ ) [64] on heavily leached, infertile sandy soils with extremely low $P$ availability [65].

Although these examples show that some of the most species-rich plant communities on Earth occur on strongly weathered, infertile soils, such broad-scale comparisons do not enable strong causal inference between pedogenesis and plant diversity, because different regions can have very different geological and evolutionary histories (e.g., recent glaciations at higher latitudes). Soil chronosequences, by contrast, enable comparisons between ecosystems within much smaller regions, where factors such as climate and parent material are controlled $[50,51]$. The available data reveal that total plant species richness usually increases with soil age across soil chronosequences spanning boreal, temperate, subtropical, and Mediterranean climates $[4,5,24]$ (Figure II). Together, these global and smallerscale patterns motivate the search for underlying mechanisms that can explain the greater plant diversity on older soils.
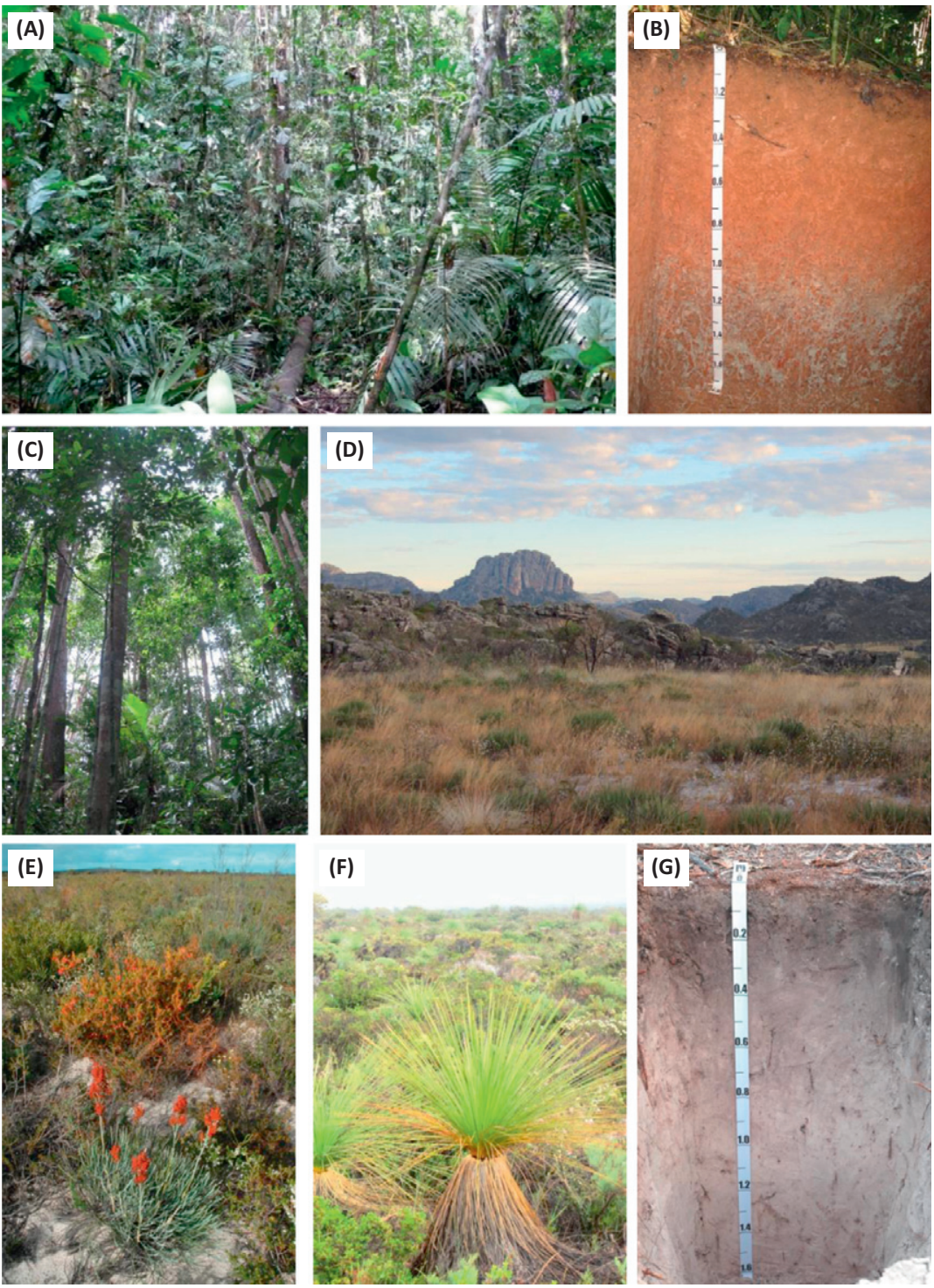

\section{(1)}

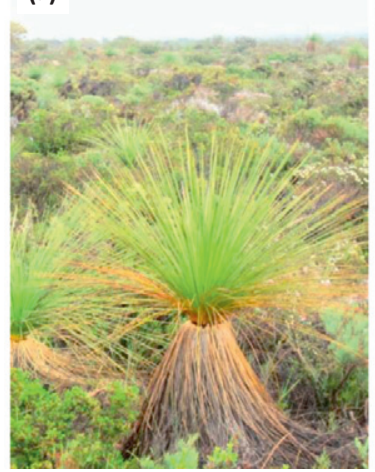

Figure I. Examples of species-rich plant communities on strongly weathered, infertile soils. Lowland tropical rainforest in Yasuní National Park (A) and associated soil profile (B), showing a strongly weathered kaolinitic Ultisol. Tropical rainforest in Lambir Hills, Malaysia, (C) and Brazilian cerrado (D). Southwestern Australian kwongan shrublands (E,F) and associated soil profile (G), showing a very thick $(0.6$ to $>1.6 \mathrm{~m})$ and conspicuously bleached $E$ horizon. Reproduced, with permission, from the Smithsonian Tropical Research Institute (A), Benjamin Turner (B and C), Graham Zemunik (D), and Etienne Laliberté (E-G). 


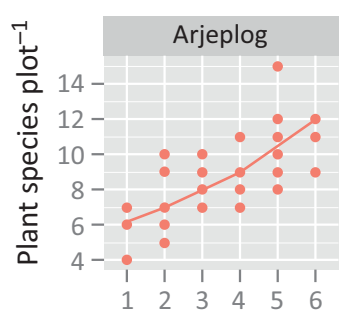

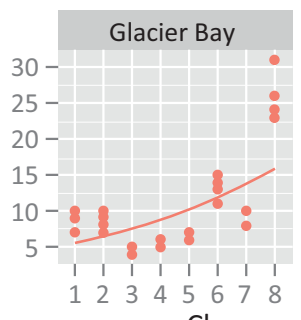

Chro

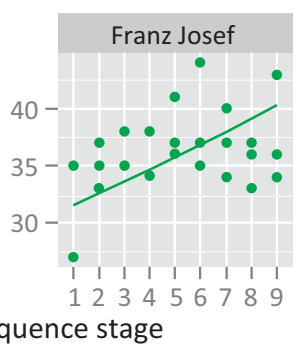

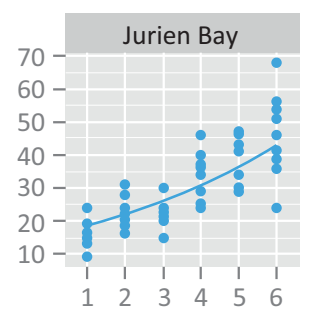

$\overline{\text { TRENDS in Ecology \& Evolution }}$

Figure II. Increases in plant species density with soil age (represented by the ranked variable 'chronosequence stage') for four representative soil chronosequences from contrasting climates. All of these soil chronosequences include retrogressive stages [9,30]. Data are from [5], except data from the Jurien Bay chronosequence [10], which are unpublished (Graham Zemunik). Points represent individual plots, which were 0.01 ha in size for the Jurien Bay chronosequence and 0.03 ha for the three others [5]. Meta-analysis of six chronosequences (these four plus two others in [5] for which data were available) reveal an overall highly significant increase in plant species density with soil age (Poisson linear mixed-effect model with logarithmic link, random intercepts per chronosequence and 'stage within chronosequence', random slopes per chronosequence, plot size as an offset; $\beta=0.120, \sigma=0.028, z=4.28, P \leq 0.0001$; no evidence for overdispersion: $\left.\chi^{2}=127.2, \mathrm{df}=194, P=0.999\right)$. Lines in each panel represent the fitted values, taking into account random slopes and intercepts per chronosequence, but omitting the 'stage within chronosequence' random effect to improve visual clarity. Key: red circles, boreal climate; green circles, temperate climate; blue circles, Mediterranean climate.

hypotheses can be tested empirically using long-term (i.e., thousands to millions of years) soil chronosequences as model systems (hereafter simply referred to as 'soil chronosequences') (Box 2). Finally, we describe how our conceptual model can serve as a meta-model for quantitative evaluation using structural equation modeling [6]. In doing this, we hope to stimulate and guide research along soil chronosequences on multivariate controls over plant diversity, particularly those that operate belowground.

\section{Potential factors controlling plant diversity Nutrient availability and stoichiometry}

The availability and stoichiometry of nitrogen $(\mathrm{N})$ and phosphorus $(\mathrm{P})$, the two nutrients that most often limit terrestrial primary productivity [7], vary strongly during long-term soil development [8,9]. $\mathrm{N}$ is generally absent from soil parent material and enters ecosystems via $\mathrm{N}_{2}$ fixation and atmospheric deposition, whereas $\mathrm{P}$ is derived predominantly from rock weathering and declines as soils age [8]. As a result, primary productivity is initially low and N-limited on young soils, increases and then becomes co-limited by $\mathrm{N}$ and $\mathrm{P}$ on intermediate-aged soils, and eventually decreases as it becomes P-limited on old soils, a phenomenon termed 'ecosystem retrogression' [9,10].

The large changes in $\mathrm{N}$ and $\mathrm{P}$ levels during pedogenesis, and associated changes in primary productivity, are relevant because nutrient availability and stoichiometry are central to some classical theories of plant species coexistence [11-13]. On the one hand, 'productivity-diversity' theories suggest that nutrient availability drives primary productivity, which in turn influences the rate at which plant species can be displaced competitively from a community [11,13]. On the other hand, resource-ratio theory [12] proposes that the balance in the supply of two (or more) limiting resources determines how many plant species can coexist, provided that species show trade-offs in their ability to acquire and tolerate low levels of these resources.

Following productivity-diversity theories, plant diversity should be low at high productivity sites where competitive exclusion is most rapid, and increase as productivity declines. Soil chronosequences provide some support for the productivity-diversity hypothesis, in that total plant species richness generally increases as ecosystem retrogression proceeds (and productivity declines) [4,5]. By contrast, according to the resource-ratio theory [12], higher plant diversity is maintained under equilibrium conditions if multiple resources limit productivity [14], such that a positive relation is expected between the number of colimiting resources and plant diversity [14]. However, the available evidence suggests that plant species richness along soil chronosequences is not greatest on intermediate-aged soils [5], where multiple nutrient limitation is most likely [10]. For example, evidence for multiple nutrient limitation [N, P, potassium (K), and/or micronutrients] along the Jurien Bay chronosequence is only found on relatively species-poor young to intermediate-aged soils ( $<7000$ years), whereas $\mathrm{P}$ is the only limiting nutrient on older soils ( $>120000$ years) [10], where plant diversity is greatest (Figure II in Box 1).

How to test the productivity-diversity and resourceratio theories? Evaluating productivity-diversity theories requires measurements of soil nutrient availability and primary productivity to be linked with data on local plant diversity along soil chronosequences. To test the resourceratio theory, intraspecific foliar $\mathrm{N}: \mathrm{P}$ ratio can be used as a measure of $\mathrm{N}: \mathrm{P}$ stoichiometry. Higher plant diversity would be expected at intermediate leaf $\mathrm{N}: \mathrm{P}$ ratios, indicative of a more balanced nutrient supply [15]. In addition, empirical tests of resource-ratio theory should involve nutrient-addition experiments (e.g., [14]), especially given recent findings that $\mathrm{N}, \mathrm{P}$, and $\mathrm{K}$ can limit different aspects of primary productivity in species-rich lowland tropical forest growing on strongly weathered soils [16].

\section{Diversity of $N$ and $P$ forms}

The classical view of resource partitioning is that if different resources limit the growth of two species, then coexistence is possible because competition is greater within than between species [17]. However, $\mathrm{N}$ and $\mathrm{P}$ occur in a variety of chemical forms in soils. Plants can take up $\mathrm{N}$ in both inorganic (nitrate and ammonium) and organic (amino acid and small peptide) forms [18]. Plants take up $\mathrm{P}$ as dissolved orthophosphate, yet soil $\mathrm{P}$ occurs in many other inorganic (e.g., pyrophosphate and polyphosphate) and organic (e.g., nucleic acids, 


\section{Box 2. Pedogenic changes along long-term soil chronosequences}

Pedogenesis involves a series of processes that includes the accumulation of organic matter, a decline in $\mathrm{pH}$, the formation of clays and metal oxides and their leaching from surface to subsurface horizons, changes in nutrient concentrations, and the formation of pans or other cemented horizons that restrict the downward growth of roots. The occurrence and rates at which these processes contribute to soil formation depend on the soil-forming factors: climate, organisms, relief, parent material, and time [57]. For example, soils develop more rapidly under a warm wet climate than under a cold dry climate, due to more intense weathering and leaching, and conifers promote rapid soil development compared with deciduous trees through the acidifying properties of their litter. Topography influences several factors, such as erosion rate, so that soil development is retarded on steep slopes compared with flatter surfaces. Parent material can include a variety of substrates (e.g. volcanic lava or ash, glacial moraine, dune sands, and bedrock exposed by landslides or geologic uplift) and has a pronounced impact on soil formation. For example, soil development occurs more slowly on impenetrable bedrock compared with loose and weath- erable material, such as glacial till. Soil chronosequences isolate the influence of time as a soil-forming factor by controlling for the remaining four factors (Figure I).

It is of particular significance for plant diversity that pedogenesis results in predictable changes in nutrient availability that are consistent across ecosystems developing under different climates and on various parent materials [9]. Most parent materials contain little $\mathrm{N}$ but abundant $\mathrm{P}$, which promotes $\mathrm{N}$ fixation by symbiotic and heterotrophic microbes and $\mathrm{N}$ accumulation in young soils. Over time, soil $P$ declines through loss by leaching that exceeds inputs from bedrock weathering, whereas chemical transformations in the soil promote the accumulation of organic and recalcitrant inorganic forms of $P$ [8]. The latter, often termed 'occluded $P$ ', represent $P$ bound strongly to, or within, metal oxides that are of limited availability to most plants. The overall effect of these processes is a long-term reduction in $\mathrm{P}$ availability, until a terminal steady state is reached when outputs in leachate balance $P$ inputs from the atmosphere. This eventually constrains plant biomass and productivity, which is termed 'ecosystem retrogression' [9].
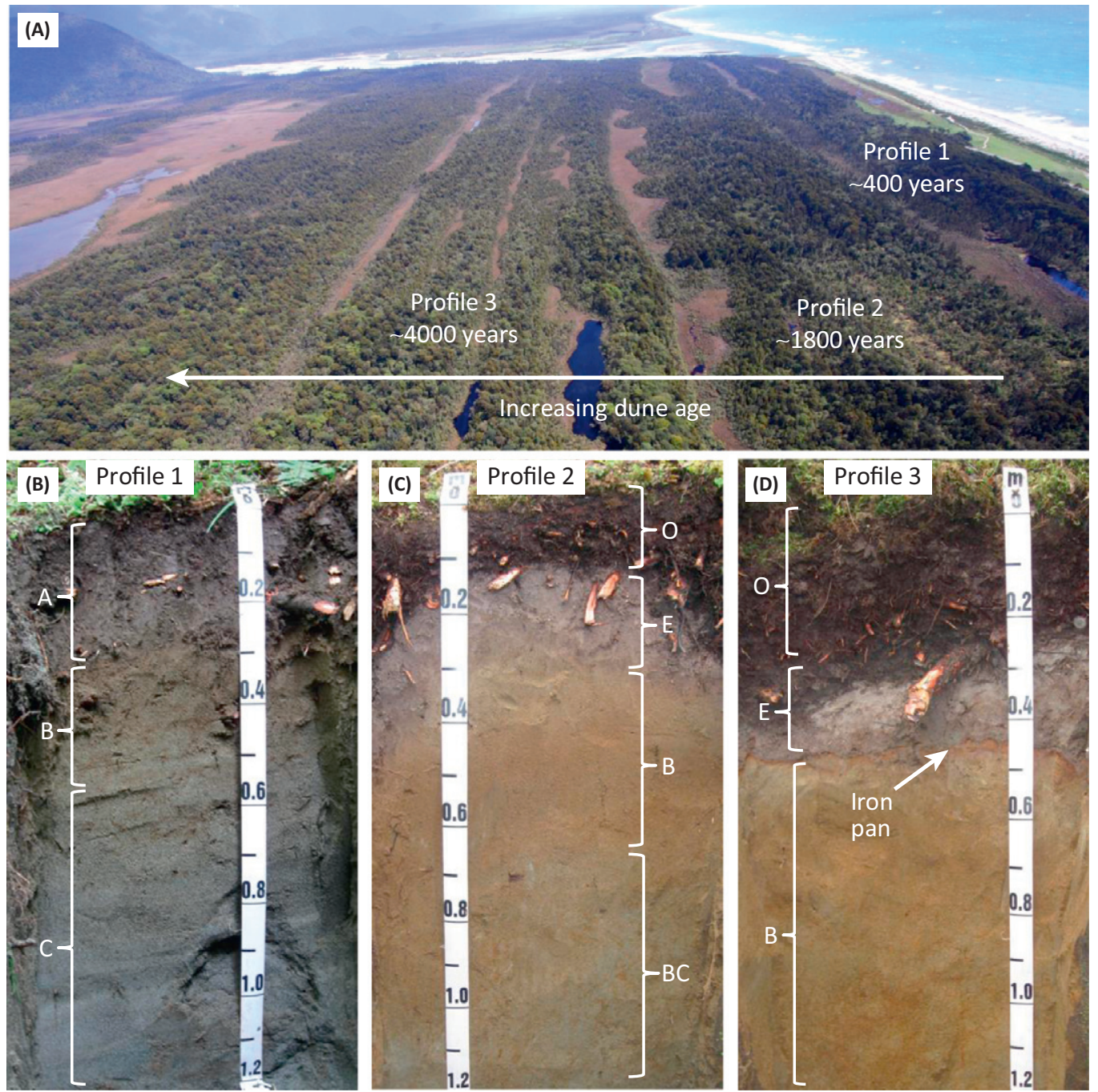

$\overline{\text { TRENDS in Ecology \& Evolution }}$

Figure I. Example of soil development in coastal sand dunes at Haast, on the west coast of the South Island of New Zealand [66] (A). Soils developed under lowland temperate rain forest in sand deposits formed following periodic earthquake disturbance along the Alpine fault. Pedogenesis is rapid under the warm and wet climate. (B) Weakly developed soil (Entisol) approximately 400 years old. The profile exhibits limited horizon development, with an organically enriched A horizon on the surface, a shallow illuvial B horizon showing faint coloration from iron oxides, and a C horizon comprising the parent sand. (C) Moderately developed soil approximately 1800 years old. The profile shows a thick organic horizon over a bleached eluvial (E) horizon from which iron oxides have been removed, and a $B$ horizon in which iron oxides are accumulating. (D) Well-developed soil approximately 4000 years old. This soil is a Spodosol and differs from the intermediate-aged soil by its thicker organic horizon, spodic $B$ horizon containing accumulated metal oxides, and a continuous cemented iron pan immediately below the $E$ horizon that impedes water movement and root penetration. These changes are accompanied by strong acidification during the early stages, an accumulation of total $\mathrm{N}$, and a marked decline in total $\mathrm{P}$ [66]. Reproduced, with permission, from Andrew Wells (A) and Benjamin Turner (B-D). 


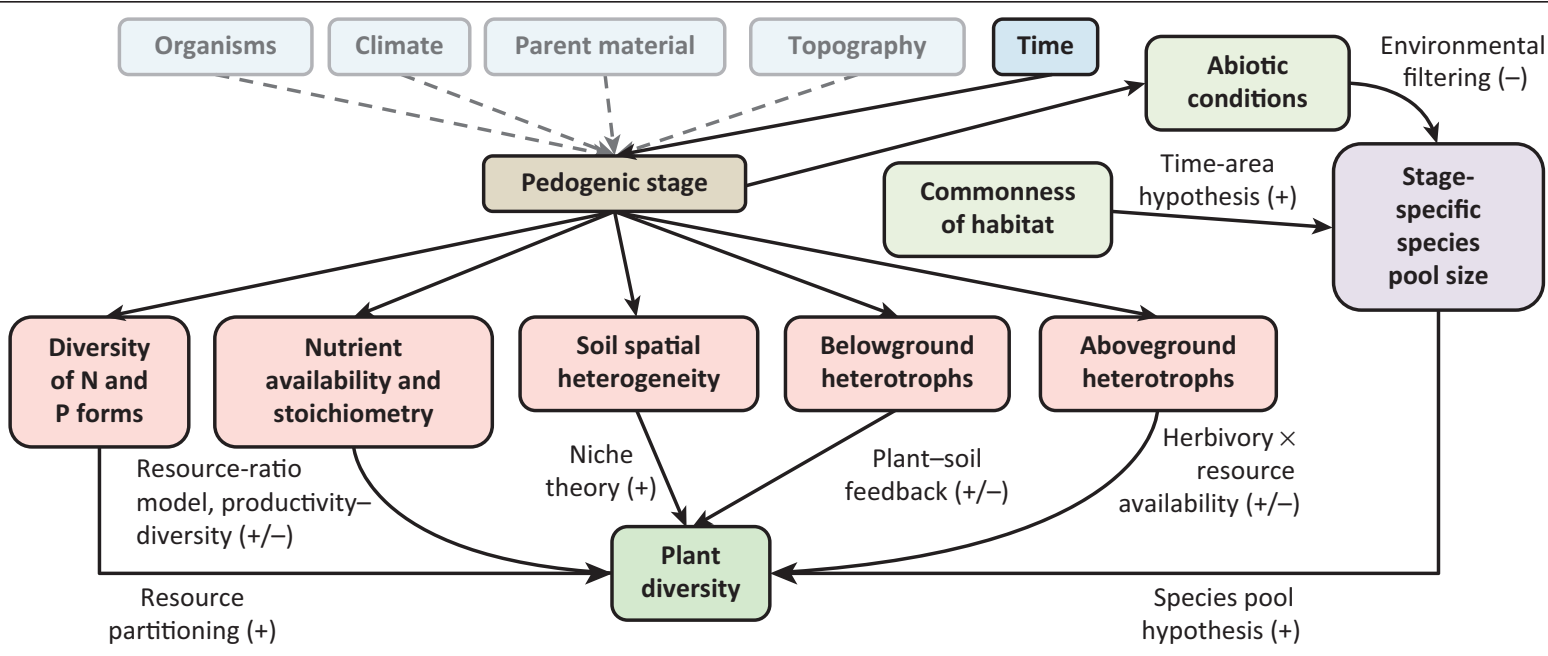

TRENDS in Ecology \& Evolution

Figure 1. General conceptual model representing how soil-forming factors (top, blue) can drive local plant diversity (bottom, green). Relevant theories are listed next to arrows. Blue boxes with broken arrows going to 'Pedogenic stage' indicate the main soil-forming factors [57] that are controlled for by using the chronosequence approach $[50,51]$ and, therefore, can be omitted from the model. Relevant theories and hypothesized effects $(+$, positive; - , negative; $+/-$, nonlinear or context dependent) are shown next to the arrows. Abbreviations: $\mathrm{N}$, nitrogen; $\mathrm{P}$, phosphorus.

inositol phosphates, phospholipids and phosphonates) forms that plants can access via specialized root strategies (e.g., mycorrhizas, phosphatase enzymes, and carboxylate exudation) $[19,20]$. This raises the possibility that partitioning of different forms of $\mathrm{N}$ or $\mathrm{P}$ can contribute to plant species coexistence, even if all species within a community are limited by the same nutrient [20,21]. In other words, a greater diversity of $\mathrm{N}$ or $\mathrm{P}$ forms in soils might allow a greater number of plant species to coexist.

The relative importance of different forms of $\mathrm{N}$ and $\mathrm{P}$ varies greatly during pedogenesis. During the progressive phase of ecosystem development, there are increases in nitrification and $\mathrm{N}$ mineralization [22]. As a result, peak productivity coincides with a relatively 'balanced' supply of inorganic and organic $\mathrm{N}$, potentially generating a greater opportunity for $\mathrm{N}$ partitioning. As retrogression proceeds, more of the total soil $\mathrm{N}$ pool occurs in less available organic forms (e.g., protein-tannin complexes), $\mathrm{N}$ mineralization rates decrease strongly, and a larger proportion of $\mathrm{N}$ is supplied as amino acids [23,24]. Partitioning of organic $\mathrm{N}$ would still be possible where the majority of the soluble $\mathrm{N}$ supply is in the form of amino acids, given that plant species can show preferences for specific amino acids or peptides [18]. However, because productivity is typically Plimited during the retrogressive phase of ecosystem development $[10,25]$, partitioning of organic $\mathrm{N}$ is likely to be less important in promoting plant species coexistence on old soils. By contrast, although total soil $\mathrm{P}$ declines over time, organic $\mathrm{P}$ accumulates during pedogenesis to become a major fraction of the remaining total $\mathrm{P}$ [8], and different forms of organic $\mathrm{P}$ vary in their relative abundance as soils age [26]. Therefore, partitioning of $\mathrm{P}$ could become important for coexistence in retrogressive ecosystems where $\mathrm{P}$ is limiting [20]. However, no study has yet quantified the importance of these mechanisms in driving diversity patterns during long-term pedogenesis, although there is growing interest in shifts in the belowground traits of plants and plant functional diversity along soil chronosequences [27].
How to test the $N$ and $P$ partitioning hypotheses. The $\mathrm{N}$ and $\mathrm{P}$ partitioning hypotheses imply that diversity in $\mathrm{N}$ forms could promote plant diversity in younger, N-limited ecosystems, whereas diversity in $\mathrm{P}$ forms would be important in older, P-limited ecosystems. The simplest test of these hypotheses would be to: (i) measure fluxes of different $\mathrm{N}$ and $\mathrm{P}$ fractions along a soil chronosequence, using established methods [18,26]; (ii) quantify the diversity of $\mathrm{N}$ or $\mathrm{P}$ fractions, using standard metrics [e.g., Simpson diversity index $(1 / D)]$; and (iii) relate the diversity of $\mathrm{N}$ or $\mathrm{P}$ forms to observed plant species diversity and determine whether these relations depend on soil age.

\section{Soil spatial heterogeneity}

Spatial heterogeneity in nutrient availability or other environmental factors that regulate it (e.g., soil $\mathrm{pH}$ ) could influence the number of plant species that can coexist via niche partitioning [17]. In other words, if different species are adapted to different nutrient levels, then a larger number of plant species might be able to coexist where there is greater spatial heterogeneity. Despite the long history of niche theory, the influence of small-scale spatial heterogeneity in soil properties on plant diversity remains little studied. In addition, how spatial heterogeneity in soil properties changes with soil development remains unclear, although one hypothesis is that more productive (e.g., in our context, intermediate-aged) ecosystems show lower spatial heterogeneity. This is expected because productive ecosystems host larger plants that forage over larger areas, thereby integrating variation in resource availability and reducing plant diversity [28].

How to determine the effect of spatial heterogeneity. One of the few studies to explore the effects of spatial heterogeneity on plant diversity during long-term pedogenesis measured within-community spatial variability in five soil properties $\left(\mathrm{NH}_{4}-\mathrm{N}\right.$, amino $\mathrm{N}, \mathrm{PO}_{4}-\mathrm{P}$, microbial biomass, and litter decomposition rate) and related it to changes in plant community composition and species richness along 
the Arjeplog island chronosequence (Figure II in Box 1) in Sweden [29]. In that system, smaller islands are less frequently burnt and, therefore, have a thicker humus layer, which is associated with slower cycling of nutrients and, thus, lower productivity [30]. Surprisingly, spatial heterogeneity in soil properties was lower on smaller islands (i.e., those with older, nutrient-poor soils), which supported the highest plant species richness [29]. Although these results suggest that spatial heterogeneity in resources does not explain differences in plant species diversity between young and old soils, further tests are required in other systems.

\section{Role of aboveground heterotrophs}

Aboveground herbivores can alter the survival, growth, and competitive interactions of plants by removing plant biomass either selectively or nonselectively depending on whether the herbivores are specialists or generalists. The effects of herbivores on plant diversity can be positive, negative, or neutral, and are strongly influenced by herbivore feeding preferences, as well as by soil fertility and the productivity of the environment, which influences the ability of plants to replace lost tissue [11,31]. Herbivore biomass and the intensity of herbivory are generally affected by soil fertility and plant productivity [32], so that total herbivory is expected to decline with decreasing soil fertility during long-term pedogenesis.

Herbivory generally promotes plant diversity more in productive or fertile environments than in unproductive and infertile areas, because the preferred species in productive areas are also more likely to be the dominant species [31]. With reference to chronosequences, positive effects of herbivory on diversity are expected to be greatest on sites where soil fertility and plant productivity are highest (i.e., in intermediate-aged soils) and plant diversity is comparatively low. Less positive, or even negative, effects of herbivory on diversity are expected where productivity is low, both on the youngest soils (where diversity is typically lowest) and on the oldest soils (where diversity is generally highest). Invertebrate herbivore density and/ or herbivory have been shown to both decrease [33] and increase [34] with declining fertility as ecosystem retrogression proceeds, but the influence of foliar herbivores on plant diversity patterns observed along soil chronosequences remains unstudied.

How to determine the role of aboveground heterotrophs. Evaluating the effects of aboveground consumers on plant diversity requires measurements of the intensity of herbivory (e.g., the proportion of primary productivity lost to herbivores), so that the effects of herbivory on plant diversity can be compared at different soil fertility levels [35]. However, the intensity of herbivory can be difficult to measure and generally requires herbivore-exclusion approaches (e.g., [36]).

\section{Role of belowground heterotrophs}

Long-term pedogenesis leads to major changes in soil biota, such as bacteria, fungi, and nematodes [37]. Soil biota can influence plant diversity by promoting resource partitioning [38], or by facilitating resource sharing via belowground pathways (e.g., mycorrhizal networks [39]). The potential for soil biota to influence plant diversity is high because most plant species depend on soil microbes for nutrient uptake [40].

Of particular relevance to plant species coexistence is the role of soil biota in 'plant-soil feedback', whereby plants influence soil biota, which in turn affect plant performance [41]. Negative feedback occurs when a plant has stronger negative effects on its own species than on its competitors, thus promoting coexistence [42]. Positive feedback, in which a species affects its environment in a way that favors itself, can lead to dominance [42].

How to determine the role of belowground heterotrophs. There is evidence that the strength and direction of plantsoil feedback depend on environmental context, particularly nutrient availability [43,44]. To address this further, controlled feedback experiments [45] using plant species and soils collected along soil chronosequences are needed to determine whether and how plant-soil feedback drives plant diversity during pedogenesis. Such experiments compare the growth of a plant species in soil conditioned by the same species versus its growth in soil conditioned by other co-occurring plant species [41], known as the 'self-other' approach [45]. Provided that a reasonable number of species per community is used, a community-level plant-soil feedback effect can be estimated [45], which can then indicate the contribution of plant-soil feedback to the maintenance of plant diversity. In that case, a stronger mean negative feedback should be associated with greater plant diversity [42].

\section{Species pools}

Whereas the mechanisms discussed so far involve local interactions between plants and soils, it has been suggested that evolutionary history can also contribute to local plant diversity patterns by determining the size of species pools [46]. The 'species pool hypothesis' proposes that plant species richness in a local community is directly influenced by the number of species that can potentially colonize the site and are physiologically adapted to the local environmental conditions [46]. For example, it has been suggested that the higher local plant diversity of older Hawaiian islands simply reflects their larger regional species pools, due to more opportunities for colonization and speciation [4]. However, many chronosequences cover a sufficiently small area that most species can disperse easily across the entire area (e.g., [10]). Differences in abiotic conditions between different pedogenic stages (e.g., young vs old islands) could still filter out those species from the regional species pool that have poor local fitness, leading to a 'stage-specific species pool' (Figure 1).

How to test the species pool hypothesis. Although estimating stage-specific species pool size can be challenging, one option is to use nonparametric species richness estimators (e.g., Chao-2) [47] on all vegetation samples from a given pedogenic stage to determine the 'true' asymptotic number of species present in that habitat [48]. According to the 'time-area hypothesis', habitats (and their associated abiotic conditions) that have been more abundant over 
evolutionary time are predicted to have a larger species pool and, thus, greater local species richness [49]. As a result, soil chronosequences can enable evaluation of the relative contribution of local versus 'species pool' effects to local plant diversity.

\section{Using soil chronosequences to investigate mechanistic controls over diversity}

Pedogenesis operates over thousands to millions of years, which vastly exceeds the timespan of any manipulative experiment. Pedogenesis can, however, be studied by using

\section{Box 3. From general theories to quantitative models}

Historically, links between theories and empirical tests have been informally determined, often resulting in unresolved debate (e.g., [54]). Recent advances in quantitative modeling provide more rigorous guidance for evaluating the multiple and simultaneous underlying mechanisms using data [6]. Furthermore, there has been an infusion of new ideas into quantitative modeling, such as the discovery that it is necessary to formalize causal reasoning for artificial intelligence systems [55]. These ideas are now being incorporated into SEM, providing a stronger foundation for developing and testing multivariate models [67].

The SEM process begins by considering the goals of the analysis. For understanding how pedogenesis drives plant diversity, our modeling is 'mediation focused'; that is, we wish to determine the dominant mechanisms that mediate the effects of pedogenesis on diversity. The general problem then becomes one of hypothesizing alternative mediating mechanisms, identifying measures that can serve as 'indicators' for underlying mechanisms, and then testing the direct and indirect causal implications of models [6]. This sequence of operations produces both an evaluation of the strengths of hypothesized linkages and the discovery of new linkages not predicted by our initial theories. Model results can then force the reconsideration of the original hypotheses and lead to designing additional studies to refine and generalize our understanding of the system of interacting processes.

Translating our initial conceptual ideas (see Figure 1 in main text) into a fully specified SEM (Figure I) requires attention to several issues. First, theoretical ideas are often only defined at the linguistic level. General concepts must therefore be carefully specified before they meet the criterion of being theoretical 'constructs' [6]. Of particular importance is the question of whether a construct is expected to have general, unidimensional influences in the system (i.e., behave as one entity) or whether it is in fact a collection of separate processes that are weakly correlated with one another (i.e., behave as a collection of entities) Second, one must consider the level of mechanistic or causal detail used to interpret relations. Will probabilistic associations (direct links) be sufficient characterizations, or are there specific causal chains needed to represent a particular mechanism? Third, what observations will serve as indicators of the underlying latent mechanisms? In Table I, we summarize the translation process for latent variables with a direct effect on plant diversity.

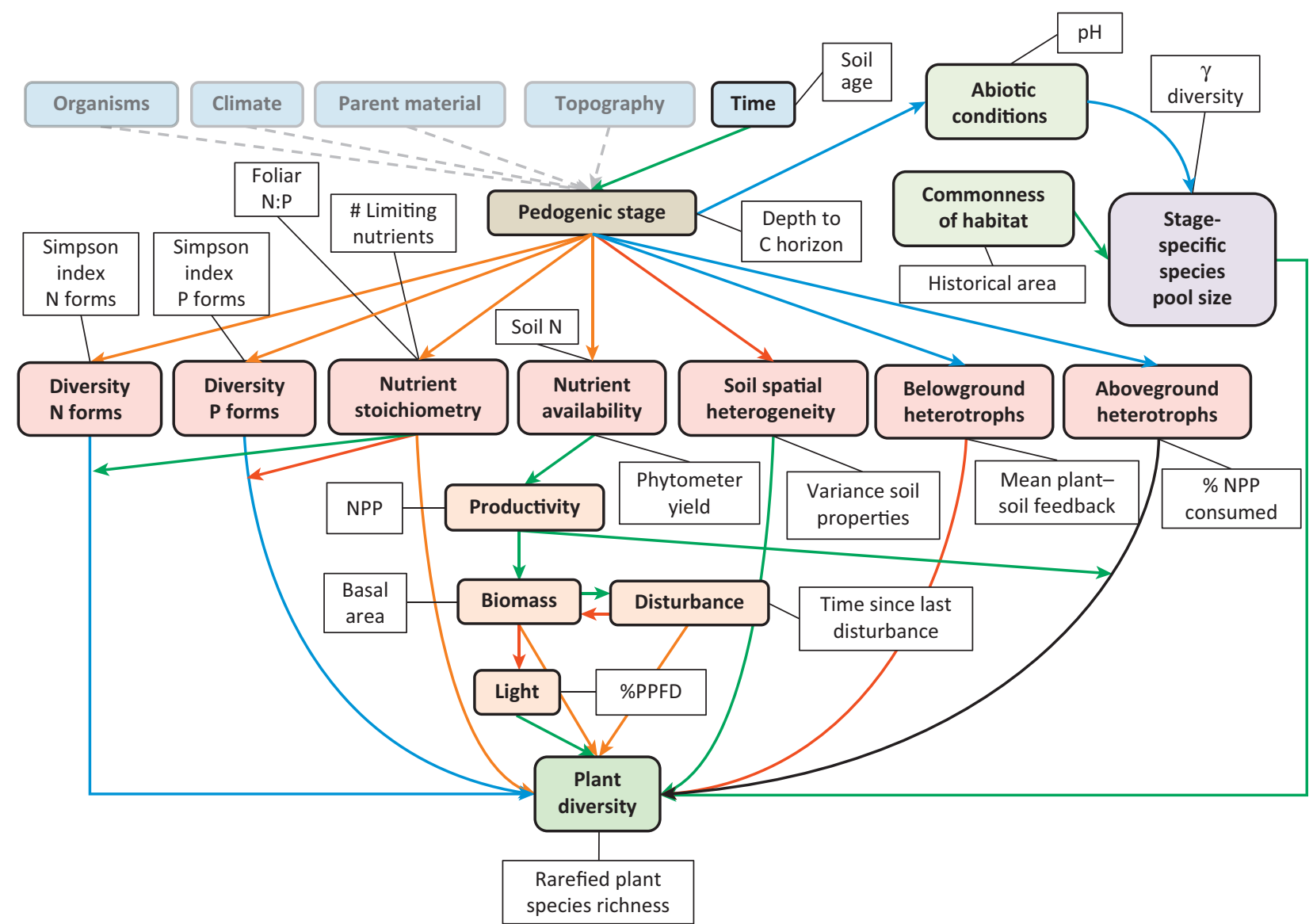

$\overline{T R E N D S}$ in Ecology \& Evolution

Figure I. Structural equation model showing indicator variables (square white boxes) for the theoretical constructs (colored rounded boxes, bold characters). Blue boxes with broken arrows going to 'Pedogenic stage' represent the main soil-forming factors [57] that are controlled for by the chronosequence approach [50,51] and, therefore, can be omitted from the model. Arrows leading to other arrows indicate interactive effects, whereby one variable influences the relation between two other variables. Abbreviations: \#, number of; \%PPFD, percent photosynthetic photon flux density at ground level; N, nitrogen; NPP, net primary productivity; P, phosphorus. Key: green arrows, positive effect; red arrows, negative effect; orange arrows, nonlinear effect; blue arrows, context-dependent effect. 
Table I. The translation process from a general theoretical model (Figure 1, main text) to a quantitative model for latent variables with a direct effect on plant diversity (Figure I)

\begin{tabular}{|c|c|c|c|c|}
\hline Construct & Indicator(s) & Justifications for indicator & How to measure & $\begin{array}{l}\text { Justifications for effect on plant } \\
\text { diversity }\end{array}$ \\
\hline $\begin{array}{l}\text { Stage-specific } \\
\text { species pool size }\end{array}$ & $\gamma$ diversity of each stage & $\begin{array}{l}\text { Estimates the number of } \\
\text { species that can potentially } \\
\text { colonize a site and are } \\
\text { physiologically adapted to } \\
\text { the soil conditions [48] }\end{array}$ & $\begin{array}{l}\text { Nonparametric species } \\
\text { richness estimator (e.g., } \\
\text { Chao-2) [48] }\end{array}$ & $\begin{array}{l}\text { Larger species pool leads to } \\
\text { greater local plant diversity [48] }\end{array}$ \\
\hline Diversity of $\mathrm{N}$ forms & $\begin{array}{l}\text { Simpson diversity index } \\
(1 / D) \text { of } \mathrm{N} \text { forms }\end{array}$ & $\begin{array}{l}\text { Simpson index is a robust } \\
\text { diversity index that takes } \\
\text { into account relative } \\
\text { abundance }\end{array}$ & $\mathrm{N}$ fractionation [18] & $\begin{array}{l}\text { Diversity in } \mathrm{N} \text { forms increases } \\
\text { plant diversity in younger, } \mathrm{N} \text { - } \\
\text { limited ecosystems [21] }\end{array}$ \\
\hline Diversity of $\mathrm{P}$ forms & $\begin{array}{l}\text { Simpson diversity index } \\
(1 / D) \text { of } \mathrm{N} \text { forms }\end{array}$ & Same as of for $\mathrm{N}$ forms & P fractionation $[26,68]$ & $\begin{array}{l}\text { Diversity in P forms increases } \\
\text { plant diversity in older, P-limited } \\
\text { ecosystems [20] }\end{array}$ \\
\hline \multirow[t]{2}{*}{ Nutrient stoichiometry } & Foliar N:P ratio & $\begin{array}{l}\text { Intraspecific variation in N:P } \\
\text { ratio can indicate the type } \\
\text { and strength of nutrient } \\
\text { limitation }\end{array}$ & Leaf $[\mathrm{N}]$ and $[\mathrm{P}]$ & $\begin{array}{l}\text { Plant diversity is greatest at } \\
\text { intermediate } N: P \text { ratios }[12,69]\end{array}$ \\
\hline & $\begin{array}{l}\text { Number of (co)limiting } \\
\text { nutrients }\end{array}$ & $\begin{array}{l}\text { Represents how many } \\
\text { (co)limiting resources plants } \\
\text { compete most strongly for } \\
\text { [14] }\end{array}$ & $\begin{array}{l}\text { Nutrient-limitation } \\
\text { experiments }[10,14,25]\end{array}$ & $\begin{array}{l}\text { Plant diversity is greater when } \\
\text { more resources are co-limiting } \\
{[14]}\end{array}$ \\
\hline $\begin{array}{l}\text { Soil spatial } \\
\text { heterogeneity }\end{array}$ & Variance soil properties & $\begin{array}{l}\text { Represents spatial } \\
\text { heterogeneity in soil } \\
\text { properties, directly relevant } \\
\text { to niche theory }[17,29]\end{array}$ & $\begin{array}{l}\text { Multivariate spatial } \\
\text { dispersion [70] of soil } \\
\text { properties }\end{array}$ & More niches, more species [17] \\
\hline $\begin{array}{l}\text { Belowground } \\
\text { heterotrophs }\end{array}$ & Mean plant-soil feedback & $\begin{array}{l}\text { Role of belowground } \\
\text { heterotrophs on plant } \\
\text { diversity is expected to be } \\
\text { strongly driven by plant-soil } \\
\text { feedback [38] }\end{array}$ & $\begin{array}{l}\text { Community-level mean } \\
\text { plant-soil feedback [45] }\end{array}$ & $\begin{array}{l}\text { Stronger negative feedback } \\
\text { leads to greater diversity [38] }\end{array}$ \\
\hline $\begin{array}{l}\text { Aboveground } \\
\text { heterotrophs }\end{array}$ & $\begin{array}{l}\text { Percentage of NPP } \\
\text { consumed }\end{array}$ & $\begin{array}{l}\text { Direct measure of primary } \\
\text { production lost to } \\
\text { consumers [35] }\end{array}$ & $\begin{array}{l}\text { Herbivore exclusion } \\
\text { approaches [36] }\end{array}$ & $\begin{array}{l}\text { Effects of aboveground } \\
\text { consumers on plant diversity } \\
\text { depend on nutrient availability } \\
\text { [31]; in productive } \\
\text { environments, the preferred } \\
\text { species are generally the } \\
\text { dominant species, thus } \\
\text { increasing diversity [31] }\end{array}$ \\
\hline Biomass & Basal area & $\begin{array}{l}\text { Good proxy for standing } \\
\text { biomass, at least in forests }\end{array}$ & Standard field methods & $\begin{array}{l}\text { Effects on diversity other than } \\
\text { light competition }\end{array}$ \\
\hline Disturbance & $\begin{array}{l}\text { Time since last } \\
\text { disturbance }\end{array}$ & $\begin{array}{l}\text { Ecologically relevant aspect } \\
\text { of disturbance }\end{array}$ & $\begin{array}{l}\text { e.g., previous aerial } \\
\text { photos, fire scars }\end{array}$ & $\begin{array}{l}\text { Direct effects on diversity not } \\
\text { mediated by light competition }\end{array}$ \\
\hline Light & $\begin{array}{l}\text { Percent photosynthetic } \\
\text { photon flux density at } \\
\text { ground level }\end{array}$ & $\begin{array}{l}\text { Direct measure of light } \\
\text { availability relevant to } \\
\text { photosynthesis }\end{array}$ & Light meters & $\begin{array}{l}\text { Light competition is strongly } \\
\text { asymmetric and reduces } \\
\text { diversity [11] }\end{array}$ \\
\hline
\end{tabular}

space-for-time substitution [50] (Box 2). Numerous soil chronosequences driven by pedogenesis have been thoroughly investigated. By ensuring that confounding factors (e.g., elevation, aspect, rainfall, parent material, and disturbance) are minimized [9], these chronosequences have provided most of our understanding of how soils develop $[8,9,51]$. However, changes in community-level properties along soil chronosequences, such as plant diversity [5], have received less attention [9].

Soil chronosequences are less suitable for studying vegetation successional dynamics, because vegetation on older sites cannot be assumed to have gone through the same stages or number of successional cycles as that on younger sites [52]. However, chronosequences can be used to compare spatial differences in present-day community and ecosystem properties (e.g., local plant species diversity) across sites of different ages if the potentially confounding effects of succession are avoided [50].
Despite their potential, there are limitations to the use of soil chronosequences for examining factors regulating plant diversity. For example, there can be difficulties in holding some environmental controls over community and ecosystem properties constant, even through careful site selection [50]. Moreover, potential drivers of local plant diversity (e.g., soil pH, nutrient availability, water-logging, and disturbance frequency) can co-vary during pedogenesis, complicating causal interpretations. However, we believe that appropriate statistical methodologies can alleviate these problems, as we discuss in the next section.

\section{Multivariate controls over diversity}

The maintenance of plant species diversity is a multivariate problem [53]. Consequently, significant progress is more likely to arise from evaluating the relative importance of multiple drivers rather than focusing on individual ones $[53,54]$. Analytical approaches, such as structural 
equation modeling (SEM), are well suited to this task, because they enable explicit linkage of theory to data and can test all direct and indirect causal implications that are derived from a conceptual model [6] (Box 3). A key challenge, however, is how to translate a theoretical model into one that can be evaluated quantitatively [6]. Manipulative experiments can also be used to establish causality for specific mechanisms [55], although this is beyond the scope of this review. We argue that confronting a priori multivariate models derived from theory against data through the use of SEM [6] (Box 3) will strengthen the soil chronosequence approach and provide valuable insights into controls on plant diversity. To understand how long-term pedogenesis affects plant diversity, we suggest ways to translate our general theoretical model (Figure 1) into one that can be evaluated quantitatively (Figure I and Table I in Box 3).

\section{Concluding remarks}

In this review, we present a set of older [11-13] and more recent $[20,21,38,49]$ hypotheses that describe how longterm pedogenesis can drive local plant species diversity. We believe that soil chronosequences can be used to quantify the relative importance of the different mechanisms that affect plant species diversity, and how they depend on environmental context. We propose that analyzing data from soil chronosequences using structural equation modeling will advance the development and testing of multivariate theories of plant species coexistence. In particular, we suggest ways to translate our conceptual model (Figure 1) into one that can be evaluated quantitatively (Box 3). Much empirical research remains to be done on multivariate controls over plant diversity, particularly in relation to belowground mechanisms. Exploration of these issues should help us understand why some ecosystems with ancient, strongly weathered soils support an incredibly high number of plant species, whereas younger, more fertile ecosystems are often dominated by considerably fewer species.

\section{Acknowledgments}

This paper originated from a research workshop held at The University of Western Australia (UWA) on 20-25 February, 2012. Funding for this workshop was provided by UWA, specifically by the School of Plant Biology (40\%), the Pro Vice-Chancellor (Research) (40\%), and the Faculty of Natural and Agricultural Sciences (20\%). We thank G. Zemunik for providing data and photos, and A. Wells for photos. E.L. was supported by a DECRA (DE120100352) from the Australian Research Council. M.A.H. was supported by NSF OPUS Grant 0918927. H.L. and F.T. were supported by an ARC Discovery grant. D.A.W. was supported by a Wallenberg Scholars award.

\section{References}

1 Hillebrand, H. (2004) On the generality of the latitudinal diversity gradient. Am. Nat. 163, 192-211

2 Huston, M.A. (2012) Precipitation, soils, NPP, and biodiversity: resurrection of Albrecht's curve. Ecol. Monogr. 82, 277-296

3 Sánchez, P.A. (1976) Properties and Management of Soils in the Tropics. Wiley

4 Crews, T.E. et al. (1995) Changes in soil phosphorus fractions and ecosystem dynamics across a long chronosequence in Hawaii. Ecology 76,1407

5 Wardle, D.A. et al. (2008) The response of plant diversity to ecosystem retrogression: evidence from contrasting long-term chronosequences. Oikos 117, 93-103
6 Grace, J.B. et al. (2010) On the specification of structural equation models for ecological systems. Ecol. Monogr. 80, 67-87

7 Elser, J.J. et al. (2007) Global analysis of nitrogen and phosphorus limitation of primary producers in freshwater, marine and terrestrial ecosystems. Ecol. Lett. 10, 1135-1142

8 Walker, T.W. and Syers, J.K. (1976) The fate of phosphorus during pedogenesis. Geoderma 15, 1-19

9 Peltzer, D.A. et al. (2010) Understanding ecosystem retrogression. Ecol. Monogr. 80, 509-529

10 Laliberté, E. et al. (2012) Experimental assessment of nutrient limitation along a 2-million year dune chronosequence in the southwestern Australia biodiversity hotspot. J. Ecol. 100, 631-642

11 Huston, M.A. (1994) Biological Diversity. Cambridge University Press

12 Tilman, D. (1982) Resource Competition and Community Structure. Princeton University Press

13 Grime, J.P. (1973) Competitive exclusion in herbaceous vegetation. Nature 242, 344-347

14 Harpole, W.S. and Tilman, D. (2007) Grassland species loss resulting from reduced niche dimension. Nature 446, 791-793

15 Braakhekke, W.G. and Hooftman, D.A.P. (1999) The resource balance hypothesis of plant species diversity in grassland. J. Veg. Sci. $10,187-200$

16 Wright, S.J. et al. (2011) Potassium, phosphorus, or nitrogen limit root allocation, tree growth, or litter production in a lowland tropical forest. Ecology 92, 1616-1625

17 Chesson, P. (2000) Mechanisms of maintenance of species diversity. Annu. Rev. Ecol. Syst. 31, 343-366

18 Hill, P.W. et al. (2011) Vascular plant success in a warming Antarctic may be due to efficient nitrogen acquisition. Nat. Clim. Change 1,50-53

19 Lambers, H. et al. (2008) Plant nutrient-acquisition strategies change with soil age. Trends Ecol. Evol. 23, 95-103

20 Turner, B.L. (2008) Resource partitioning for soil phosphorus: a hypothesis. J. Ecol. 96, 698-702

21 McKane, R.B. et al. (2002) Resource-based niches provide a basis for plant species diversity and dominance in arctic tundra. Nature 415, 68-71

22 Vitousek, P.M. et al. (1983) Soil development and nitrogen turnover in montane rainforest soils on Hawai'i. Biotropica 15, 268-274

23 Northup, R.R. et al. (1995) Polyphenol control of nitrogen release from pine litter. Nature 377, 227-229

24 Wardle, D.A. et al. (2012) Linking vegetation change, carbon sequestration and biodiversity: insights from island ecosystems in a long-term natural experiment. J. Ecol. 100, 16-30

25 Vitousek, P.M. and Farrington, H. (1997) Nutrient limitation and soil development: experimental test of a biogeochemical theory. Biogeochemistry 37, 63-75

26 Turner, B.L. et al. (2007) Soil organic phosphorus transformations during pedogenesis. Ecosystems 10, 1166-1181

27 Holdaway, R.J. et al. (2011) Species- and community-level patterns in fine root traits along a 120 000-year soil chronosequence in temperate rain forest. J. Ecol. 99, 954-963

28 Tilman, D. and Pacala, S. (1993) The maintenance of species richness in plant communities. In Species Diversity in Ecological Communities (Ricklefs, R.E. and Schluter, D., eds), pp. 13-25, University of Chicago Press

29 Gundale, M.J. et al. (2011) Resource heterogeneity does not explain the diversity-productivity relationship across a boreal island fertility gradient. Ecography 34, 887-896

30 Wardle, D.A. et al. (2004) Ecosystem properties and forest decline in contrasting long-term chronosequences. Science 305, 509-513

31 Hillebrand, H. et al. (2007) Consumer versus resource control of producer diversity depends on ecosystem type and producer community structure. Proc. Natl. Acad. Sci. U.S.A. 104, 10904-10909

32 McNaughton, S.J. et al. (1989) Ecosystem-level patterns of primary productivity and herbivory in terrestrial habitats. Nature 341, 142-144

33 Gruner, D.S. (2007) Geological age, ecosystem development, and local resource constraints on arthropod community structure in the Hawaiian Islands. Biol. J. Linn. Soc. 90, 551-570

34 Crutsinger, G.M. et al. (2008) Ecosystem retrogression leads to increased insect abundance and herbivory across an island chronosequence. Funct. Ecol. 22, 816-823

35 Laliberté, E. and Tylianakis, J.M. (2012) Cascading effects of long-term land-use changes on plant traits and ecosystem functioning. Ecology 93, 145-155 
36 McNaughton, S.J. et al. (1996) How can net primary productivity be measured in grazing ecosystems? Ecology 77, 974-977

37 Williamson, W.M. et al. (2005) Changes in soil microbial and nematode communities during ecosystem decline across a long-term chronosequence. Soil Biol. Biochem. 37, 1289-1301

38 Bever, J.D. et al. (2010) Rooting theories of plant community ecology in microbial interactions. Trends Ecol. Evol. 25, 468-478

39 Simard, S.W. et al. (2012) Mycorrhizal networks: mechanisms, ecology and modelling. Fungal Biol. Rev. 26, 39-60

40 Van der Heijden, M.G.A. et al. (2008) The unseen majority: soil microbes as drivers of plant diversity and productivity in terrestrial ecosystems. Ecol. Lett. 11, 296-310

41 Mangan, S.A. et al. (2010) Negative plant-soil feedback predicts treespecies relative abundance in a tropical forest. Nature 466, 752-755

42 Bever, J.D. (2003) Soil community feedback and the coexistence of competitors: conceptual frameworks and empirical tests. New Phytol. $157,465-473$

43 Kardol, P. et al. (2006) Temporal variation in plant-soil feedback controls succession. Ecol. Lett. 9, 1080-1088

44 Manning, P. et al. (2008) Nitrogen enrichment modifies plant community structure via changes to plant-soil feedback. Oecologia $157,661-673$

45 Kulmatiski, A. and Kardol, P. (2008) Getting plant-soil feedbacks out of the greenhouse: experimental and conceptual approaches. Prog. Bot. $69,449-472$

46 Zobel, M. (1997) The relative role of species pools in determining plant species richness: an alternative explanation of species coexistence? Trends Ecol. Evol. 12, 266-269

47 Gotelli, N.J. and Colwell, R.K. (2001) Quantifying biodiversity: procedures and pitfalls in the measurement and comparison of species richness. Ecol. Lett. 4, 379-391

48 Grace, J.B. et al. (2011) Local richness along gradients in the Siskiyou herb flora: R.H. Whittaker revisited. Ecology 92, 108-120

49 Zobel, M. et al. (2011) The formation of species pools: historical habitat abundance affects current local diversity. Global Ecol. Biogeogr. 20 , 251-259

50 Walker, L.R. et al. (2010) The use of chronosequences in studies of ecological succession and soil development. J. Ecol. 98, 725-736

51 Vitousek, P.M. (2004) Nutrient Cycling and Limitation: Hawai'i as a Model System. Princeton University Press

52 Johnson, E.A. and Miyanishi, K. (2008) Testing the assumptions of chronosequences in succession. Ecol. Lett. 11, 419-431

53 Grace, J.B. (1999) The factors controlling species density in herbaceous plant communities: an assessment. Perspect. Plant Ecol. Evol. Syst. 2, $1-28$
54 Adler, P.B. et al. (2011) Productivity is a poor predictor of plant species richness. Science $333,1750-1753$

55 Pearl, J. (2011) The causal foundations of structural equation modeling. In Handbook of Structural Equation Modeling (Hoyle, R.H., ed.), pp. 1-36, Guilford Press

56 Sterner, R.W. and Elser, J.J. (2002) Ecological Stoichiometry: The Biology of Elements from Molecules to the Biosphere. Princeton University Press

57 Jenny, H. (1941) Factors of Soil Formation. McGraw-Hill

58 Valencia, R. et al. (2004) Yasuní forest dynamics plot, Ecuador. In Tropical Forest Diversity and Dynamism: Findings from a Large-Scale Plot Network (Losos, E.C. and Leigh, E.G., eds), pp. 609-628, University of Chicago Press

59 Korning, J. et al. (1994) Characters of three Udults and their relevance to the composition and structure of virgin rain forest of Amazonian Ecuador. Geoderma 63, 145-164

60 Lee, H.S. et al. (2002) Floristic and structural diversity of mixed dipterocarp forest in Lambir Hill National Park, Sarawak, Malaysia. J. Trop. Forest Sci. 14, 379-400

61 Ratter, J.A. et al. (1997) The Brazilian cerrado vegetation and threats to its biodiversity. Ann. Bot. 80, 223-230

62 Furley, P.A. and Ratter, J.A. (1988) Soil resources and plant communities of the Central Brazilian Cerrado and their development. J. Biogeogr. 15, 97-108

63 Cowling, R.M. (1990) Diversity components in a species-rich area of the Cape Floristic Region. J. Veg. Sci. 1, 699-710

64 Hnatiuk, R.J. and Hopkins, A.J.M. (1981) An ecological analysis of kwongan vegetation south of Eneabba, Western Australia. Aust. J. Ecol. 6, 423-438

65 Lambers, H. et al. (2010) Plant mineral nutrition in ancient landscapes: high plant species diversity on infertile soils is linked to functional diversity for nutritional strategies. Plant Soil 334, $11-31$

66 Turner, B.L. et al. (2012) Soil nutrient dynamics during podzol development under lowland temperate rain forest in New Zealand. Catena 97, 50-62

67 Grace, J.B. et al. (2012) Guidelines for a graph-theoretic implementation of structural equation modeling. Ecosphere 3, 1-44 art73

68 Hedley, M.J. and Stewart, J.W.B. (1982) Method to measure microbial phosphate in soils. Soil Biol. Biogeochem. 14, 377-385

69 Cardinale, B.J. et al. (2009) Separating the influence of resource 'availability' from resource 'imbalance' on productivity-diversity relationships. Ecol. Lett. 12, 475-487

70 Anderson, M.J. et al. (2006) Multivariate dispersion as a measure of beta diversity. Ecol. Lett. 9, 683-693 